\title{
Współczesne enoteki jako przykład budynków zaprojektowanych $w$ harmonii ze środowiskiem naturalnym
} \section{Contemporary wineries as buildings} designed

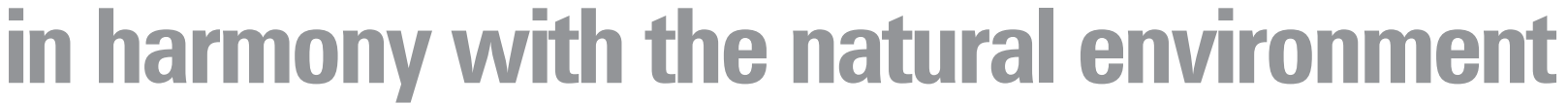

\begin{abstract}
Streszczenie
W czasach postępującego rozwoju urbanistycznego ogromne znaczenie odgrywa harmonijne wkomponowanie nowych budynków w istniejące już otoczenie oraz uwzględnienie uwarunkowań środowiskowych i klimatycznych regionu. W światowych trendach wyraźnie zaznacza się chęć kreowania architektury nowoczesnej i innowacyjnej a przy tym ściśle związanej z lokalną kulturą i tradycją. Projektowanie architektury zrównoważonej oraz bliskiej idei krytycznego regionalizmu zyskuje więc na coraz większej popularności. Jednym z założeń tej koncepcji jest bezpośrednie, dialektyczne obcowanie budynku z naturą. Kenneth Frampton opisuje, że podstawową cechą krytycznego regionalizmu jest „place-form”, czyli kształtowanie architektury silnie związanej z miejscem i terenem, na którym się znajduje, uwzględniającej grę światła, topografię oraz warunki klimatyczne. W niniejszym artykule przeanalizuję wybrane współcześnie zbudowane w Europie enoteki jako architekturę ściśle związaną przez swoją funkcję z terenami zielonymi. Postaram się odpowiedzieć na pytanie czy budynki te stworzone dla potrzeb ludzi szanujących przyrodę i czerpiących przyjemność z obcowania z nią mogą być przykładem wzorcowych rozwiązań dla projektów uwzględniających zachowanie walorów środowiska naturalnego.
\end{abstract}

\section{Abstract}

In the times of increasing urban development, harmonious incorporation of new buildings into the existing surroundings and taking into consideration environmental and climate conditions of the region plays a major role. Creating modern and innovative architecture closely connected to local culture and tradition is clearly visible in global trends. Designing sustainable architecture related to the idea of critical regionalism gains more and more popularity. One of the presumptions of this concept is direct, dialectic contact of the building and nature. According to Kenneth Frampton, the fundamental characteristic of critical regionalism is "place-form", i.e. creating architecture closely connected to the place and terrain it occupies, taking into account lighting, topography, and climate. In this paper, I will analyse selected contemporary European wineries as examples of architecture closely connected with green areas due to their function. I will try to answer the question whether these buildings, created for people respecting and enjoying the nature, can be considered exemplary solutions for designs aiming at maintaining environmental values.

Słowa kluczowe: enoteki, winiarnie, architektura regionalna, budownictwo zrównoważone, architektura zieleni, krytyczny regionalizm Key words: enoteche, wineries, regional architecture, sustainable construction, landscaping, critical regionalism

\section{WSTĘP}

Współczesna architektura staje w obliczu nowych wyzwań. Dynamicznie postępujące procesy urbanizacyjne często nie dostosowane są do naturalnych potrzeb człowieka, ale kierowane względami ekonomicznymi. Zagęszczenie miast ograniczające przestrzeń i swobodę wyboru zachowań mieszkań-

\section{INTRODUCTION}

Contemporary architecture is facing new challenges. Dynamic urbanisation processes are often based rather on economy than on natural human needs. Increasing urban density limiting the amount of space and free choice of behav- 
ców wpływa na podniesienie poziomu stresu oraz odczucie niskiego komfortu i jakosci życia.

Wzrastająca świadomość ekologiczna w połączeniu z potrzebą obcowania ze środowiskiem naturalnym doprowadziła do wypromowania w wielu dziedzinach życia idei zrównoważonego rozwoju. Architektura zrównoważona ma być odpowiedzia na wspótczesne problemy związane $z$ ekologia energetyką i zmianami klimatycznymi. W projektowaniu stara sie wykorzystywać majace jak najmniejszy wptyw na środowisko materity i cochno jo nú whaścima gospodarke odpadami. Zwraca uwage na usytuwhas mo Wanié budy i cien̂ oraz pom znaczenie ma rówhiez spojna relacja obiektu z jego bezposed z zownowazon soza sie uwz led diac rowniz aspektura zrównowazona stara się uwzględniac równiez aspekty społeczno-kulturowe, zdrowotne, poczucia bezpieczeństwa i tożsamości oraz kontaktów międzyludzkich odbiorców. Tym
samym bierze pod uwagę całoksztatt realiów przyrodniczych samym bierze

Powstaje pytanie czy projektowanie uwzględniające lokalne warunki środowiskowe i ukształtowanie terenu jest nowym trendem? Czy jest reakcją na pogarszające się warunki bytowe czy po prostu powrotem do "naturalnej architektury" tworzonej przez człowieka?

Analizując architekturę tradycyjną różnych cywilizacji na świecie, można stwierdzić, ze ludzie od zawsze projektowali w sposób zrównoważony. Budynki aby przetrwać musiały uwzględniać lokalne uwarunkowania klimatyczne i specyfikę terenu oraz przewidywać zmiany środowiskowe w niedalekiej przyszłości. W każdej kulturze istniał pewien rodzaj “ekologicznej architektury" nawet jeśli nie został on tak nazwany i opisany. Strategie przystosowawcze do zmian ekonomicznych, społecznych i klimatycznych doprowadziły niezależnie od regionu świata do wypracowania wysoce nowatorskich i specjalistycznych rozwiązań projektowych.

Z rozwiązań tych czerpie bezpośrednio architektura wernaku-

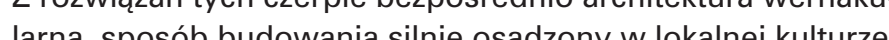
Najczésej wykorzystuje on dostepne na miejscu marze. Najczezsiej wyon ły oraz tradycyjne techniki konstrukcyjne i wykończeniowe. Wzorem jest tu praktyczne doswiadczenie i znajomosc trady-

Scisłe powiązanie architektury z obszarem, na którym się znajduje podkreślal Kenneth Framphton, który spopularyzowal zaproponowane przez A. Tzonis i L. Lefaivre pojęcie ",krytycznego regionalizmu . Zwracat on uwage na uwzględnienie kontekstu topograficznego, klimatycznego, swiatla i tektoniki w projektowaniu. Cechę tą określit jako "place-form”. Architektura regionalizująca jest refleksją twórcy nad miejscem i próbą wykorzystania analogicznego do tradycyjnego sposobu myślenia o lokalnych uwarunkowaniach. Inspiracje czerpie w sposób krytyczny, lecz progresywny².

\section{TEMATYKA}

2.1 Zielen integralną częścią środowiska zurbanizowanego Możliwość obcowania ze środowiskiem naturalnym jest jedną z podstawowych potrzeb człowieka. Elementy zieleni iour of inhabitants increases the level of stress life. Increasing environmental awareness combine with the need to commune with nature led to promoting the idea of sustainable development in many areas of life. Sustainable architecture is conecology, energetics, and climate change. It aims using materials and technologies that minimally a fect the environment, renewable energy, and proper waste management. It puts emphasis on building location optimally using sunlight and shadow, as well as helping achieve optimal air circulation. Coherent relation between the object with its surroundings is also important. Apart from its ecologcal aspects, sustainable architecture attempts to include also social and cultural, health, security, identity, and people-to-people contacts-related aspects. Thus, it takes into account all environmenta and social realities.

A question arises whether design taking into account local environmental conditions and terrai ing living conditions or just a return to "natural architecture" created by people?

Analysing traditional architecture of different cvilisations, one can notice that people have always designed buildings in a sustainable way. Lasting buildings had to be designed with local climate and topographic conditions, as well as upcoming own kind of "ecanges in mind. Each culture had ifs scribed and called this way. Strategies of adaptatio to economic, social, and climate changes led to the elaboration of highly innovative and specialised design solutions regardless of the region of the world. Vernacular architecture is an architectural style that is rooted in local culture, draws directly from these solutions. It usually uses local materials an based on practical experience, knowledge of trat tion, and respect of the context of the place and environment

Kenneth Framphton, who popularised the notion of "critical regionalism" established by A Tzonis and L. Lefaivre, emphasised close relation of architecture with its surroundings. He underlined the importance topographic, climate, light, and tectonics context in design. He called this characteristic "place-form". Region-related architecture is a creator's reflection on place and an attempt to us a way of thinking on local conditions corresponding with the traditional one. It draws inspiratio critically, but progressively. ${ }^{2}$

\section{SUBJECT}

2.1 Greenery as an integral part of urbanised environment

Contact with nature is one of basic human needs. Greenery has been a part of urban areas since anconditions, affects fauna), technical (it encloses an uwzględniane były w przestrzeniach miast od starożytności logiczne (poprawia warunki mikroklimatu, wpływa na faunę), techniczne (osłania i izoluje przestrzeń i budynki), estetyczne (wywołuje odczucia harmonii i piękna, integruje budynki z otoczeniem) i psychologiczne (daje odczucie spokoju, wzmacnia więzi z otoczeniem) ${ }^{3}$ Odpowiednio zaprojektowa na roślinność może wpływać na klimat miasta poprzez zmia ne takich czynnik nę takich czynnikow jak: charakterystyka termiczna podłoża, i zanieczszcz zonie pytow. Dzi on w sposób tagotzanie za zaso jaw cow dydakty i wyche jiweluje ona stres, daje možliwosć wypoczynku, nawiazzywania konlogiczną i uczy szacunku do przyrody. ${ }^{5}$

logiczną i uczy szacu ku do przyrody. Znaczenie zieleni w ksztattowaniu przestrzeni miejskiej podkreślała idea "miasta-ogrodu" E. Howard'a stworzona na początku XX wieku, a w dalszych latach tzw. Karta Ateńsk podpisana na IV Międzynarodowym Kongresie Architektury Nowoczesnej oraz Nowa Karta Atenska podpisana w Lizboni w 2003 roku. Ta ostatnia podkresla że: „Utrzymywanie bezpośredniego kontaktu z przyrodą jest dla ludzi nie tylko źródłem dobrego samopoczucia, ale takze warunkiem przetrwania" oraz „jakość środowiska jest jednym z podstawowych czynników gwarantujących gospodarczy sukces miasta i przyczynia się także do jego żywotności społecznej i kulturalnej".

2.2 Enoteki jako budynki ściśle związane z naturą Winnice od starożytności były uosobieniem kontaktu człowieka z naturą. Motyw winnego krzewu pojawiał sie w niemal każdej kulturze, w sztuce, ornamentach i literaturze. Wino było podstawowym napojem, źródłem energii, synonimem bogactwa czy też elementem kultu i wierzeń religijnych. Winnice uwzgledniano jako element wzbogacaiacy tereny (n) podmiejskie np. $W$ Xiv wieczn

Plantatorzy wina będący najczęściej osobami kolekcjonującymi doznania otaczali się wyrafinowaną estetyką i wyjątkowa chick izwiazyych z nimi oblektow powierane jest czesto znaym i zwiazanych z nim obiektow powizane jest często znanym swiatowym projektantom. W ostatnich latach zauwazalny jest równiez znaczący rozwoj enoturystyki - formy spędzania wo nego czasu na obserwacji uprawy latorośli, produkcji wina kosztowaniu szlachetnego trunku. Powiązanie architektury winiarni ze sztuką oraz klimatem beztroskiego zwiedzani kontemplacji przyrody doprowadzito w wielu przypadkac do powstania obiektow scisle związanych z krajobrazem oraz wielofunkcyjnych. Mają one za zadanie wypełnienie odwiedzaCzy zatem mozna odszukac we wspołczesnych enotekac rozwiązan wzorcowych dla projektowania w harmonii ze środowiskiem naturalnym? Czy plantatorzy szacunek dla przyrody przedkładają ponad oryginalność i ekstrawagancję budynku mające na celu reklamę ich produktu? Wreszcie czy możn isolates space and buildings), aesthetic (elicits senwith their surroundings), and psychological (gives the feeling of calm, strengthens relationships with one's surroundings). ${ }^{3}$ Properly designed green areas may affect city's climate through changing thermal characteristics of the soil, humidity balpoe, hermal pollution, ventilation, and particulate the inhabitants' comfort of life ${ }^{4}$ Its influease on social, educational, and pedagogical function of urban area is equally important. It removes stress, provides the possibility of rest and leisure, fosters ontacts between people. It increases ec, fosters awareness and teaches respect for nature. ${ }^{5}$

The importance of greenery in urban areas is en phasised by E. Howard's idea of garden city, formed at the beginning of the 20th century, and later in the Athens Charter signed on the 4th International Congresses of Modern Architecture, as well as the New Athens Charter signed in Lisbon in 2003. The latter mphasises that: "As human beings belong to a living species, maintaining a possibility of contact with but also a prerequisite for survival" and "Environmenta a lity is a major factor in guaranteeing the

2.2 Wineries as buildings strictly related to nature Wineries have been the epitome of contact between man and nature since antiquity. The motif of vine has been present in almost every culture in art, ornaments, and literature. Wine has been the primary beverage, source of energy, synonym of wealth, as well as an element of cult and religious beliefs. Wineries were an element enriching suburban areas for example in 14th century Pais,
they were established in its southern part.

they were established in its southern part.
Vine growers, who often collected experiences, Vine growers, who often collected experiences,
liked sophisticated aesthetics and unique architecture. Winery architecture has been dynamically developing since the 1980 s. Designing new wineries and related objects is often entrusted to famous architects. In the recent years, significant development of enotourism, consisting of observing bserved. In many cases, the connection of winery architecture with art and atmosphere of carefree visit and contemplation of nature led to the establishment of multifunctional objects closely tied with the surrounding landscape. Their objective is experiences, as well as a chance to relax.

Therefore, can one look for model solutions for design in harmony with natural enviroly important for wine growers than extravagnce and originality aiming at advertising their products? Finally, can respect for the place and sustainable design be combined with remarkable and multifunctional architecture?

Are these buildings a reinterpretation of traditiona 
połączyć szacunek dla miejsca i zrównoważone projektowanie z niebanalną i wielofunkcyjną architekturą?

Czy budynki te stanowią reinterpretację tradycyjnych rozwiazań a przez to moga wpisać się w nurt architektury krytycznego regionalizmu

\section{ZAKRES ANALIZY ARCHITEKTONICZNEJ}

W niniejszym opracowaniu analizie architektonicznej pod kątem zastosowania rozwiązań projektowych cechujących architekture zrównoważona $i$ uwzgledniajaca uwarunkowania klimatyczne i środowiskowe zostaną poddane wybrane enoteki powstałe na świecie w XXI wieku.

Skodyfikowane standardy i systemy oceny architektury zrównoważonej nie wpływają na ograniczenie rozwiązań architektonicznych. Warunkują one jednak jakość architektury poprzez wpływ na jej poszczególne cechy.

Wśród cech, które będą brane pod uwagę podczas analizy są: - lokalizacja budynku i uwzględnienie kontekstu miejsca

- forma budynku (wykorzystanie naturalnej topografii, światła i klimatu)

- integracja budynku z otaczającym terenem

- wykorzystanie elementów zieleni i wody

- sprzyjające środowisku naturalnemu rozwiązania funkcjonalne

- stosowanie materiałów proekologicznych oraz odnawialnych źródeł energii

\section{ARCHITEKTURA UKRYTA W KRAJOBRAZIE}

Położenie enoteki $w$ bezpośrednim sąsiedztwie rozległych terenów winnicy stawia przed projektantami wymóg stworzenia budynku uwzględniającego charakter miejsca i nie zakłócającego harmonii otaczającego krajobrazu. Jednocześnie architekci chcąc tworzyć w sposób nowoczesny i innowacyjny muszą znaleźć odpowiednią proporcję między funkcjonalnością, zachowaniem tradycji, a nowatorskimi rozwiązaniami. Znamienne są również wymagania inwestora, dla którego istotny jest najbardziej proces technologiczny tworzenia wina i związane z nim specyficzne warunki klimatyczne.

Budynkiem, który idealnie zespolił środowisko naturalne

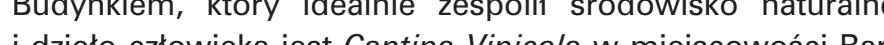
i dzielo czlowieka jost Cantina Vinicola w miejscowości Bargino we Woszech. Bryla pomino swojej znacznej kubatury zyróż có dowicie wisana w zielone zbocze. Nie da się w niej wyrónic dachu ani elewacj. Patrząc z daleka widzimy tylko wzgóze winorosli przerwane horyzontalnie dwoma poziomymi liniami oraz 11. Whe do srodka [il. 1]. Whętrza wykonane zostaly z regionalnych materiałów jak drewno i piaskowiec pietra serena. Nowoczesne technologie produkcyjne zostały tutaj zaaranżowane w układzie wysokościowym. Zebrane winogrona przemiesz czane są wraz z grawitację od zbocza w dót, przez zbiorniki fermentacyjne do podziemi gdzie leżakuje wino. Przeciwnie odwiedzający, którzy rozpoczynając swoją podroż od parkingu wędrują w górę obserwując etapy produkcji aż do sali degustacji na górnych kondygnacjach.

Bodega Brugaro/ autorstwa pracowni RCR Aquitectes jest przykładem autentycznej piwnicy winiarskiej $w$ dawnym tego słowa znaczeniu. Budynek schowany pod obszarami winnicy solutions and thus can fall within the trend of critical regionalism?

3. SCOPE OF ARCHITECTURAL ANALYSIS In this paper, selected wineries constructed in the 21 st century will undergo architectural analysis in the light of the use of architectural solutions charconsideration climate and environmentat contitions.

Codified standards and sustainable architecture evaluation systems do not limit architecturetur tions. However, they condition the quality of architecture by affecting its particular traits.

The characteristics covered by the analysis include:

building location and place context

building form (using natural topography, light, and climate)

- integration of the building with the surrounding terrain

using elements of greenery and water

functional solution in favour of the environment

4. ARCHITECTURE HIDDEN IN THE LANDSCAPE The fact that a winery is located near wast vineyard terrains requires architects to design a building taking into account the character of the place and not disturbing the harmony of the landscape. At the same time, architects, wanting their creations to be modern and innovative, have to find the right proportion between functionality, tradition, and innovative solutions. The investor's requirements, focused on technological process of wine production and related specific climate conditions, ar also important.

The building that perfectly united natural environment and human creation is Cantina Vinicola in fully integrated in the green slope. One cannot distinguish its façade or roof. Looking from a distance, one sees only a vineyard on a hill crossed by two horizontal lines and oval holes letting in light [il. 1 . The interior was made from natural materials such as wood and pietra serena sandstone. Modern production technologies were arranged vertically. Grapes move downwards: down the hill, through digesters, to the undergrounds, where wine matures. Visitors move in the opposite direction, as they start on the parking lot and move upwards, observing production steps, and finally get to the

Bodega Brugarol by RCR Arquitectes is an example hidden under the vchool wine cellar. The building, a path between bushes and vines. Built of concrete narrow weathered steel plates, and rocks, it is closely connected with red granite soil rich in iron. The visitors walk on compacted sand and gaps between the plates allow air, vine roots, and light that creates constantly changing patterns in. Steel and
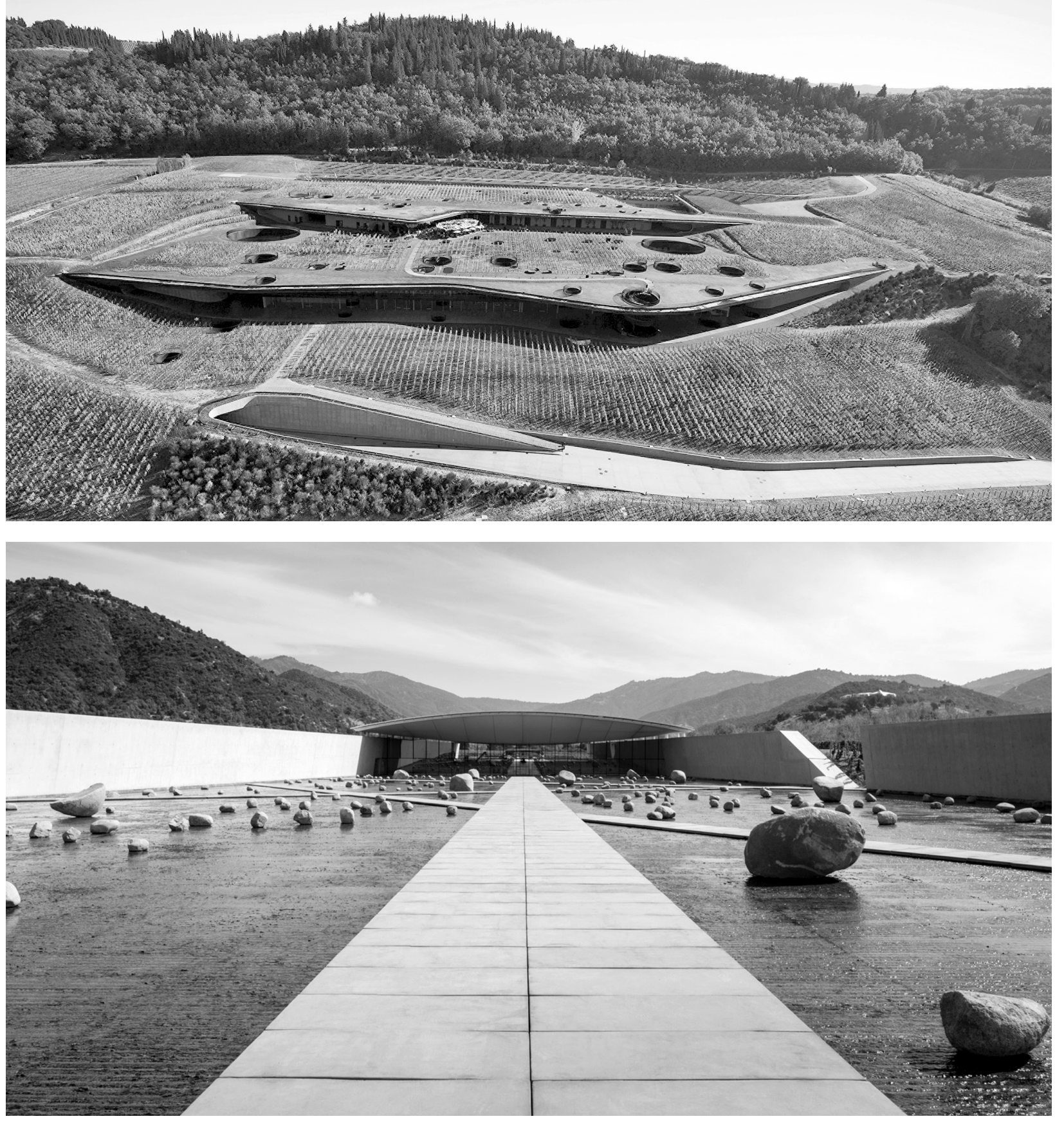

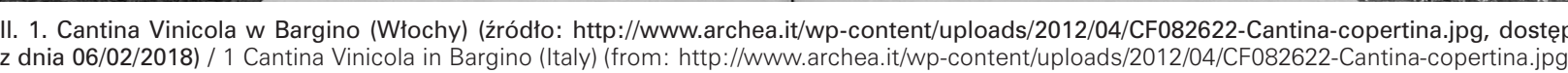

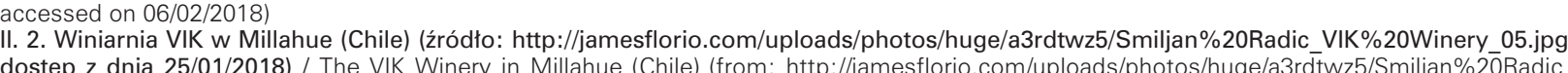
dostep z dnia 25/01/2018) / The VIK W Winery in Millahue (Chile) (from: http://jamesflorio.com/uploads/photos/huge/a3rdtwz5/Smilian\%20 Radic
VIK\%20Winery 05.jpg, accessed on 25/01/2018)

dostępny jest poprzez ścieżkę prowadzącą przez krzaki i winorośla. Zbudowany z betonu, wąskich płyt ze stali kortenow skiej i kamieni ściśle łączy się z czerwoną, granitową gleba bogatą w żelazo. Odwiedzający stąpaja po ubitym piasku, a przerwy między płytami na ścianach wpuszczają powietrze korzenie winorośli i światło, które wpadając do pomieszczen tworzy ciągle zmieniający się wzór. Stal i kamień oraz podziemna aranżacja sal wielofunkcyjnych pozwala na naturalna regulację temperatury i wilgotności potrzebne do produkci wina. Architekci pracujący na kanwie światła i cieni stworzy strukturę gdzie spotyka się architektura, rzeźba i krajobraz. rock, as well as the arrangement of undergroun mulfichnal rooms, allows natural temperature duction Arch adusts working basad for wine prodich architecture, sculpture, and landscape.

Another example of a winery integrated into land scape is the VIK vineyard by a Chilea a landSmiliaj Radic. Situated in Millahue in the Andes, it combines modern technologies, design, and minimal impact on the environment. It has a fla rransparent roof made of fabric, which lets natura 
Kolejnym przykładem enoteki płynnie wkomponowanej w otaczający krajobraz jest Win chilijski architekt Smiliaj Radic. Położona w miejscowości Millahue, pomiędzy szczytami Andów została zaprojektowana tak by połączyć nowoczesne technologie, design i minimalny wpływ na przyrodę. Konstrukcja winnicy charakteryzuje się płaskim, przeźroczystym dachem z tkaniny, która pozwala przeniknaćc naturalnemu świattu do wnetrza. Większość budynku znajduje sie pod ziemia aby wykorzystujac naturalna amplitude termiczna doliny regulować warunki naturalną Wejście do winnicy stanowi dustopniowy pochyly phji. prez który plynie soda prez kioy plyie woda bedaca dodichow pochentem

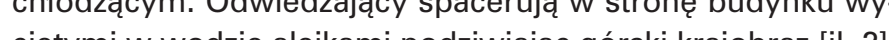

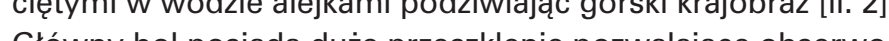
Gać panorase Andowi presone tereny winicy. wac panorą Andowi izelone tereny winnicy.

Wyjątkowym połączeniem tradycji, poszanowania przyrody i zrownoważonego rozwoju jest Winiarnia IXSIR w miejscowości Basbina wibanie. Sercem budynku jest 140-letni historyczny dwor z grubymi murami kamiennymi arkadami. Jego klasyczny, dalekowschodni styl nie wskazuje na to, że na nizszej kondygnacji znajduje się nowoczesny zakład produkcyjny. Przemieszczając się schodami w dół powoli przechodzimy od bloków białego kamienia do betonowe piwnicy. Znajduje się ona 12 metrow pod ziemią i pokryta jest zielonymi terenami winnicy. Całkowite zagłębienie w gruncie produkcji zapewnia odpowiednią równowage temperatury i wilgotności. Przez otwory w zielonym dachu przenika światło dzienne, a otwarte usytuowanie przestrzeni z kadziami na północny-zachód pozwala na naturalny przepływ powietrza. Położona w górach Batrum winnica, której nazwa pochodzi od arabskiego słowa eliksir (Al-Ikseer) jest mieszanką eleganckich linii ze starożytnym dziedzictwem. Przykładem całkowitego podporząadkowania projektu architektonicznego morfologii krajobrazu jest Winiarnia Herdade Do Freixo w Redondo w Portugalii. Projekt minimalizuje wptyw na typowy krajobraz Alentejo - pofałdowany, zróż cowany z kepami dzikich dzzen oliwnych, drzeny, zrożnii ostrokrewu. Kilkukondygecyiny budynek osadzonębu greboks 40 metrón pod zieyia co pozwlito na wykory glębokosc 40 mikn pod ziemia, co pozwolino na wykorzy

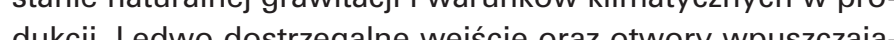
dukcki Le wo dowe ce światio i powietre sạ jedynymi elementami świadczącym o winiarni w topografii terenu. Winnicę tá można zaliczyć do
architektury podziemnej („„earth sheltered").

\section{SZACUNEK DLA TRADYCJI I ŚRODOWISKA}

\section{NATURALNEGO}

Zdecydowanie większe wymagania przed architektami nowych winnic stanowią miejsca, w ktorych oprocz zielonych terenów uprawnych znajdują się budynki historyczne, zwiazzane z produkcją wina. Poszanowanie tradycji, nawiązanie do klasycznych wzorców, a przy tym stworzenie architektury niebanalnej i nowoczesnej wymaga duzego wyczucia. Szczególnie w krajach gdzie tradycja wyrobu wina jest ściśle związana z lokalną kultura. Obiekt nowej winiarni i winoteki w Château Margaux we Francji zrealizował te trudne zadania. Budynek autorstwa Norma- light in. Most of the building is underground, which allows using natural temperat valley to regulate production conditions. At the entrance to the building, there is a two-level slanting yard covered with water, which is an additiona cooling element. The visitors walk to the entrance on alleys crossing the water, admiring the mouning allowing observing the panorame of Andes and green areas of the vineyard. (XXSR Wination of tradition, respect for nature, and sustainable development. The core of the building is a 140 years old mansion with thick walls and stone arcades. Its classical Middle-Eastern style does not reveal that there is a modern production plant. In the cellar, white stone blocks are replaced by concrete. The cellar is situated 12 metres underground and covered by green areas of the vineyard. Placing the whole production process underground assures appropriate temperature and humidity balance. Light enters through holes in the roof and open position of the vats area to in the mountains, the winery the name of which derives "Iksir", the original Arabic word for "Elixir" combines elegant lines and ancient heritage.

An example of subordinating an architectural design to the landscape is the Herdade Do Freixo Winery in Redondo, Portugal. The design minimis es the influence on typical Alentejo landscape undulating, diverse, with wild olive trees clusters, oaks, and holly. The multi-floor building is seated 40 metres underground, which allowed making use of natural gravity and climate in production. Barely noticeable entrance and holes letting light and air in are the only elements marking the presence of the whey in the of

\section{RESPECT FOR TRADITION AND NATURAL}

ENVIRONMENT

Places with not only cropland, but also historica bigger challenge for architects. Respect for trach tion and referencing classical style inc with original and modern architecture requires a great sense, in particular in countries where win production tradition is closely related with local culture.

The new winery in Château Margaux in France meets these demanding requirements. The building, designed by Norman Foster, is located on the east side of an early 19th century complex. It has an open, elastic form in perfect harmony with exby reinterpreting the roof of the histerical mostly The winery has a gabled roof on the san ling built of tiles recovered from nearby ruins with addition of glass letting in sunlight [il. 3]. Its innovative load-bearing structure in the shape of trees is a result of cooperation between architects and constructors. In order to minimise the interference

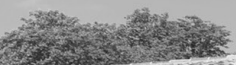

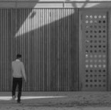

$=$
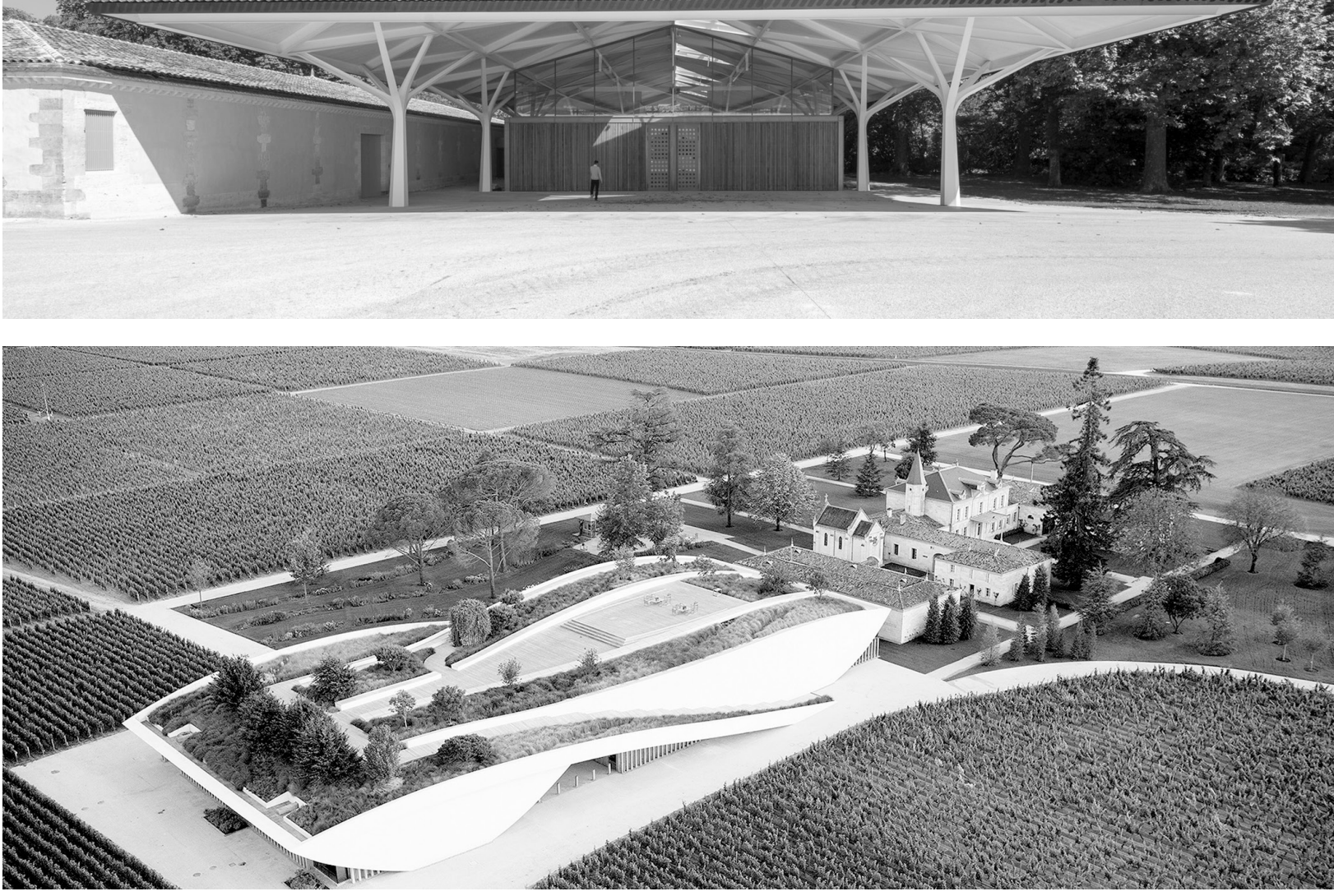

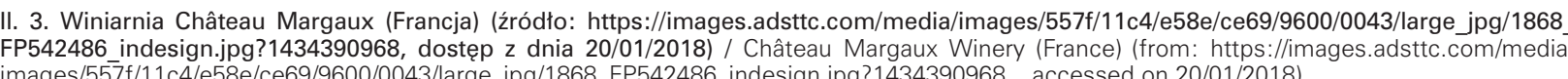

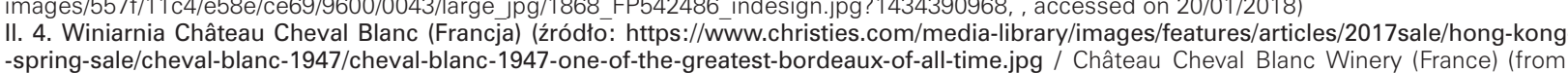

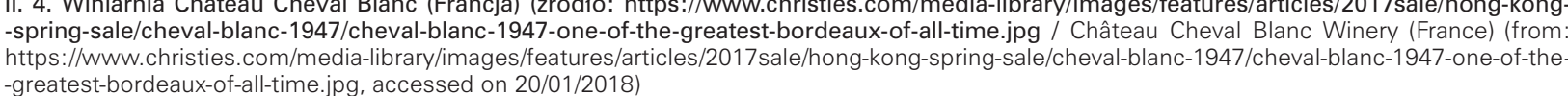

na Fostera rozciaga sie od wschodniego skrzydła kompleksu z Foczatku XIX wieku Posiada otwarta, elastyczna forme, która idealnie harmonizuje $z$ istniejącymi budynkami przemysłowymi. Uzyskano to przede wszystkim przez reinterpretacje dachu historycznego budynku. Winnica posiada dwuspadowy dach na tym samym poziomie, zbudowany z odzyskanych ze sasiadujących ruin starych dachówek i przeplatany lekkimi szybami wpuszczającymi światto dzienne [il. 3]. Innowacyjna konstrukcja nośna mająca kształt drzew była wynikiem pracy zespołowej między architektami i konstruktorami. Pod winnica, aby zminimalizować ingerencję $\mathrm{w}$ krajobraz ukryto nowa mającą 70 metrów długości winotekę. Nowy obiekt zapewnia cas czenie do przechowywania słynnych butelek Château Margaux. „Poprzez odkrycie ruin w sąsiednim miejscu, możliwe with the landscape, a 70-metre long wine house was hidden under the winery. The new object assures a safe and environment-friendly storage space for the famous Château Margaux bottles. By investigating ruins elsewhere on the site it was possible to recycle enough tiles to create another major roof in the same vernacular. The new winery is rooted in the technology of today and the best of these traditions it is of the place in both the culture of the local architecture and the industry of wine making.

Another exceptional building in the middle of vineyard shaped throughout ages is Châtea Cheval Blanc. The new winery is placed in immedate proximity to the Saint-Emilion castle. It is situated under the undulating structure of green roof 
było odzyskanie wystarczającej ilości dachówek by stworzyć kolejny nowy dach w sposob wernakularny. Nowa winiarnia jest zakorzeniona we współczesnej technologii oraz najlepszej tutejszej tradycji - jest "z tego miejsca” zarówno w kulturze lokalnej architektury jak i branży produkcji wina" - wskazuje Foster. (tłum. własne). ${ }^{9}$

Niezwykłym budynkiem w środku winnicy ukształtowanej na przestrzeni wieków jest Château Cheval Blanc. Nowa winiarnia leży w bezpośrednim sasiedztwie zamku z Saint-Emilion. Znajduje sie pod ogromna falista struktura zielonego dach Który wychodzi wprost $z$ historycznego obiektu otwo dachu na piekny krajobraz [il. 4]. Betonowa konstrukcja ma széćc krzywoliniowych ścin 4l. Be chych polaczonych sze mien besc krywoly kuych scin. 4l. Besych polaczo śm szeregiem be-

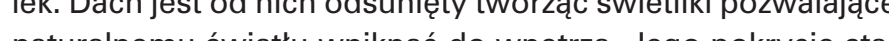
naw . nowi okazaly ogrod pelen zieleni polączony wizualnie i prze-

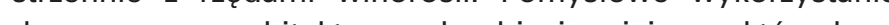
drewna przez architekta w celu objęcia miejsc, w ktorych na elewacji nie ma szkła lub betonu, nadaje budynkowi charakteru. Efekt widoczny jest szczegolmie w nocy przy sztucznym oświetleniu. Na parterze znajdują się specjalnie zaprojektowane dla procesu fermentacji betonowe kadzie w kształcie szklanki do degustacji. Poniżej mieści się piwnica do przechowywania beczek, ktorej sciany wykonane zostaly w technice mashrabiya ${ }^{10}$, aby ułatwić naturalną wentylację. Budynek, który zaprojektował Christian de Portzamparc jest znaczącym osiągnięciem w branży winiarskiej na całym świecie. Uzyskal on bowiem jako jedyna winiarnia certyfikat dla standardu wysokiej jakości środowiskowej (HOE). Certyfikat ten ocenia m.in. staranność przy doborze materiałów budowlanych, oszczędność energii, gospodarowanie odpadami oraz zbieranie i sortowanie odpadów, a także komfort akustyczny i dobre samopoczucie pracowników.

Przykładem budynku zespalającego istniejąca architekturę $\mathrm{z}$ nowo powstała jest Cantina Colterenzio we Włoszech. Celem projektu było potaczenie winiarni z jej budynkami z la 60 i 80 oraz nadanie jej świeżego wyrazu Architekci uzyskal

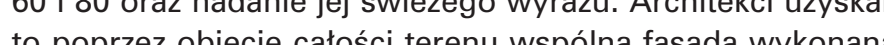
to poprzz obje ci losci $z$ dębowych pacie i i i nowa przen pan i i maca, who sie $i$ jest unieszczo w odlogi $50 \mathrm{~cm}$ od sciany budyna Fazow un oszzona w odeglosci socm od sciany budynku. fazowan obramowa o istniejacych drzw i okien z ocynkowanej $i$ lakierowanej blachy podkreslaja otwory w fasadzie zachowujac jej oryginalną formę i strukturę. Kontynuacją elewacji jest stalowa kratownica na ktorej zaprojektowano zieloną scianę. Znajdujące się na niej rozznorodne gatunki roślin od jaśminu zimowego do dzikiego wina wiją się w górę przekształcając ją w sezonie wegetacyjnym w kolorowe, pachnące patio. Dach winiarni pokrywają panele fotowoltaiczne zapewniające $30 \%$ zapotrzebowania na energię elektryczna oraz panele solarne i system odzyskiwania ciepła dające $70 \%$ niezbędnej ciepłej wody.

Budynek Château Barde-Haut w Saint-Christophere-des-Bardes we Francji jest przykładem architektonicznej obecności, która szanując siłę miejsca nie rywalizuje, ale dynamicznie rozwija. Obiekt powstał w bezpośrednim sąsiedztwie kamien- projecting directly from the historical object, opening to the beautiful landscape [il. 4). The concre structure has six curved-line load-bearing walls connected by beams. The space between them and the roof creating skylights letting natural ligh in. It is covered by a splendid green garden visually and spatially connected with vine rows. Creative where there is no glass or concrete adds character to the building. The effect is visible particularly at night, in artificial lighting. Concrete tanks in form of tasting glass, designed specially for the fermentation process, are located on the ground floor. Below, there is a cask storage cellar with walls made in mashrabiya ${ }^{10}$ technique to facilitate natural air circulation. The building, designed by Christian de Portzamparc, is an important achievement in world's wine industry. It is the only winery to obtain the high environmental quality standard (HOE) certificate. The certificate evaluates, among other things, careful choice of building materials, energ saving, waste management, sorting, and collection, as well as acoustic comfort and well-being o

A example of a building combining existing and aim of the project was to connect the winery with its buildings from the 1960s and 1980s and giving it a fresh look. Architects achieved it by encircling the entire area with a common façade made of oak panels and metal mesh. It created a new connecting space with technical facilities. Oak panels refer to wine barrels and are placed $50 \mathrm{~cm}$ from the building walls. Chamfered frames of existing doors and windows are made of galvanised powdercoated steel and bring attention to the openings in the façade while maintaining its original form and structure. A steel grill covered by a green wall is a continuation of the elevation. Diverse plant speering it coil upwards, transforming it into a colourful and aromatic patio during the growing season. The roof of the winery is covered with photovoltaic panels providing $30 \%$ of electrical energy needed solar panels, and heat recovery system providing $70 \%$ of hot water needed.

Château Barde-Haut in Saint-Christophere-desBardes in France is an example of a building that respects the power of the place, developing it dynamvcally instead of competing with it. The object was built in immediate proximity to low 19th century houses. The façade line matches the existing buildings. Weathered steel was chosen as a combination of old and new materials. This interesting interaction creates a new story. Solutions characteristic for The buildings are isolated for an optimal therma slowness. Canadian wells and hot air pumps were dug along the line of the building. The green roof reproduces the topography of the area, strengthen insulations, and filters rainwater, which is purified and used in production. On the roof, there is also a wind turbine supplying the entire external lighting.

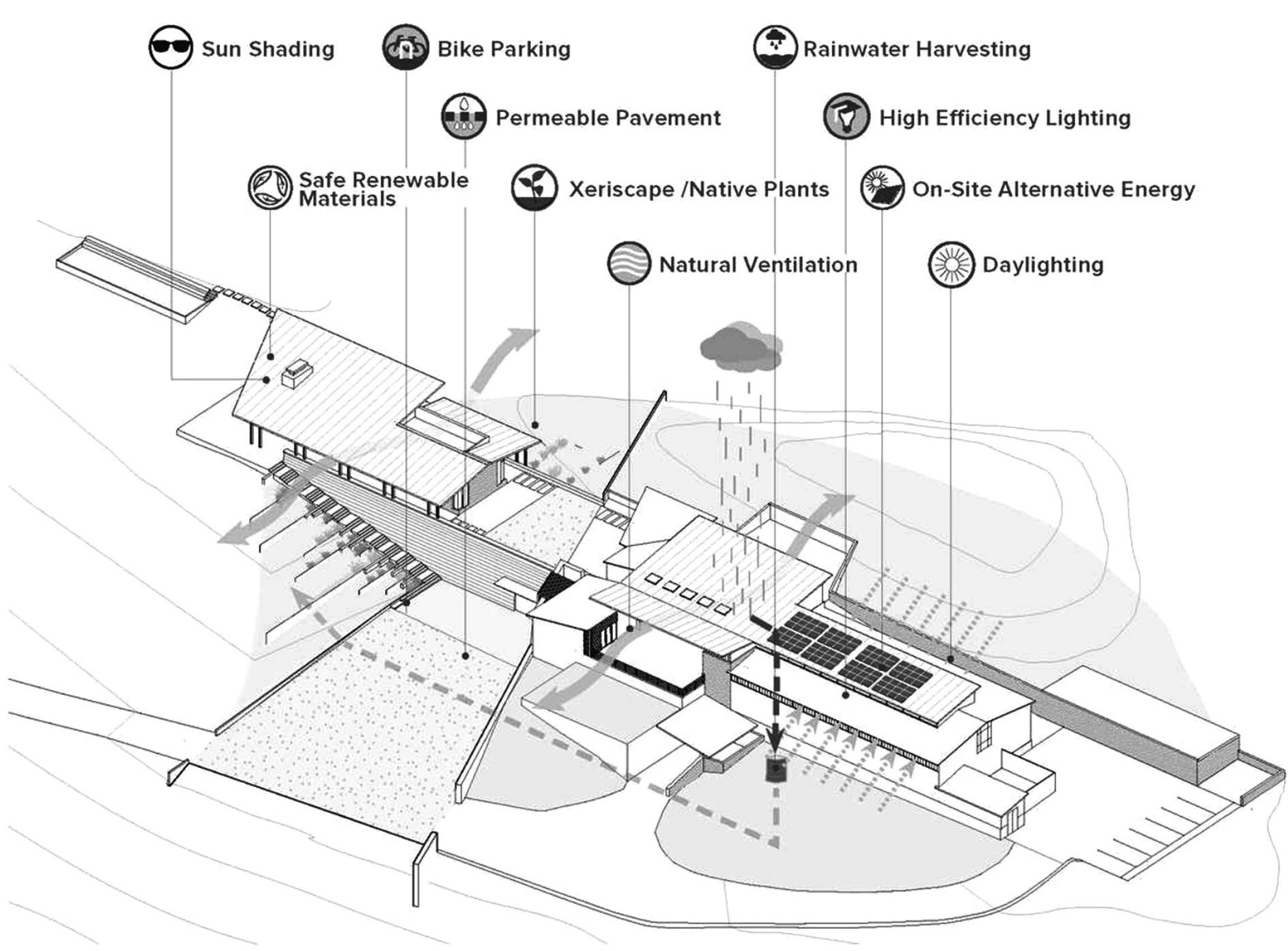

SUSTAINABILITY DIAGRAM । $\mathbb{1}$

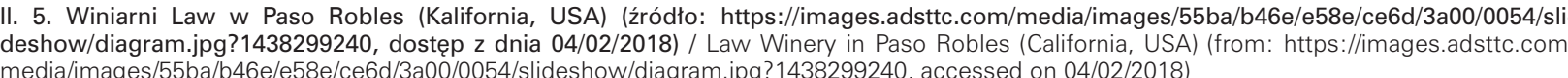

nych niskich domów z XIX wieku. Linia fasady jest dopasowana do istniejących budynków, a jako połączenie materiałów tradycyjnych z nowoczesnymi wybrano stal kortenowska. Ta ciekawa interakcja tworzy nowa historię. W projekcie zostały zastosowane rozwiazania cechujace architekture zrómnowa żona. Budynki sa izolowane aby zapewnić optymalna dynamike termiczna wzdłuz obrysu zainstalowano studnie dynadyiskie oraz pompy ciepla. Zielony dach oltwarza topografie dyjskie oraz pompy ciepla. Zie zin do do ografie jo joczyszczana i uzywa wa wroduki. Na daczu zajduje sérón

Czestym rozwiazaniem w nowo projektowanych winiarniac jest zagłębienie ich $w$ terenie. Zmniejsza ono zapotrzebowanie energetyczne oraz ułatwia zapewnienie warunków termicznych i wilgotności potrzebnych dla produkcji. Architekci stosują również inne sprzyjające środowisku naturalnemu stosują równic

Do budowy Winiarni Law w Paso Robles w Kalifornii użyt bezpiecznych, odnawialnych materiałów budowlanych - stal drewna i szkła. Skośny kształt dachu zapewnia odpowiednia osłonę przed nadmiernym nasłonecznieniem, a jego otwarty układ wspomaga naturalną wentylację pomieszczen. Odpowiednio zaprojektowane przeszklenia maksymalizują użycie światła dziennego. Zastosowano panele fotowoltaiczne ra-
A popular solution in newly designed wineries is immersing them in the ground. It reduces energy demand and maks and humidity needed for production easier. How ever, architects also use other environment-frien y solutions.

construction of the Law Winery in Paso Robles rials, such as steel, wood, and glass, were used Slanting roof prevents excessive insulation and its openness supports natural ventilation of the rooms. Glazings maximise the use of sunlight Moreover, photovoltaic panels, energy-saving lighting, and rainwater harvesting system were used. Over the cellar area, there is a green roof covered with local plants. It minimises additional irrigation. A lane made of permeable materia leads to the entrance and bike parking [il. 5]. Port Phillip Estate Winery in Australia situated on vineyard's undulating terrain near Westpor Bay is also an example of ecological construc tion. The rammed-earth exterior walls and large eaves shield interior spaces from the afternoon glazing throughout the project rances Doubro loss. The museum wine store and barrel room are situated 7.5 metres below ground level, forming a natural cellar with ideal humidity and tempera- 
zem z energooszczędnym oświetleniem oraz system zbierania wody deszczowej. Nad obszarami piwnic znajduje sie zielony dach pokryty lokalną roślinnością i zaprojektowany tak aby zminimalizować dodatkowe nawadnianie. Do wejścia prowadzi droga z przepuszczalnej nawierzchni zakończona parkingiem dla rowerów [il. 5].

Winiarnia Port Phillip Estate w Australii znajdująca się na falistym terenie winnicy niedaleko zatoki Westernport jes także przykładem ekologicznego budownictwa. Zewnetrzosłaniaja wnetrza od potudniowego słońca, zapewniajac doskon izolaci W calym projekcie zastosowano pod wójne

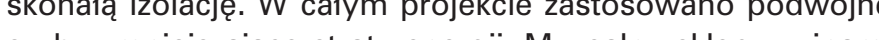
szyby zm is i piw zice beczek zlokizowano 7,5m ponizej poziomu gruntu dla uzyskania pozadanych wa pan przechowywania. Panele sloneczne podgrzewaja wodę i kontroluja temperaturę, a energooszczędne oswietlonie zmniejsza zužycie energi o okolo 80\%. Whiarnia nie jest podiączona do sieci wodociągowej więc cala woda uzyskiwana jest $w$ sposób autonomiczny. Budynek posiada instalację odzyskiwania i oczyszczania zużytej wody. Ponadto zbierana jest woda deszczowa, która filtruje się przez złoże trzcinowe zanim zostanie zmagazynowana i użyta do nawadniania winnicy. Wodę deszczową z dachu poddaje się oprócz oczyszczania działaniu światła ultrafioletowego, aby można było ją wykorzystać do natrysków i picia. Rozwiązania te są częścią filozofii architektów bycia odpowiedzialnym za środowisko naturalne.

Budynek winiarni Casa Uco w Argentynie został zaprojektowany w sposób minimalistyczny. Bryła przypomina kształtem teleskopową stodołę. Jej wielkość rośnie stopniowo wraz ze zmianą funkcji wewnętrznych, które zlokalizowane sa w jednym podłużnym ciągu. Konstrukcja mająca długość $100 \mathrm{~m}$ wykonana jest $z$ betonu i metalowych płyt dajacych wysoką izolacje cieplna. Otwarta orientacja winiarni z zachodu na wschód umożliwia kontrolowanie ilości świtała słonecznego i naturalna wentylacje dzieki efektowi Venturiego. Wykorzystuje do tego dominuja w regionie wiatry Zonda. Winiarnia stanowi nowoczesna reinterpretacje wzorca wiejskiej siania stanchitekci projektujacy nowe wini wácz wiejskiej stodoły. tura det ench Przy sola Przyk de makjego budve jost winia BRUMA znajdujaca się w obszarze wiriarskim Valle de Guadelupe w Meksyku. Symbolem i centralną osią obiektu jest 300 letni dąb rosnący pośrodku hali beczkowej. Materialami konstrukcyjnymi oraz wykonczeniowymi jest tutaj drewno z recyklingu, stal, ubita ziemia i skaly. Winiarnia jest zaglębiona w terenie ileży w bezpośrednim sąsiedztwie niewielkiego zbiornika wodnego, który wspomaga utrzymanie prawidłowej temperatury. Drewniane listwy na elewacji są naturalnie wyblakłe i mają różne odcienie co nadaje budynkowi interesującą i ziemistą fakturę. Wykonane w elewacji niewielkie rzędy otworów pozwalają na delikatne wnikanie do srodka swwiatła dziennego. Dach winnicy pokrywają rodzime rośliny. Część kompleksu stanowią zakrzywione ściany działowe z ubitej ziemi, które dodatkowo integruja budynek z zakurzonym, czerwono-zielonym krajobrazem doliny ture for wine storage. Solar panels heat water and has been used through out reducing the energy consumption by around 80 percent. The winery is not connected to mains water, so all water used is obtained autonomously. The building has a water recycling system. Moreover, rainwater is harvestviding additional filtration before being captured in a damn and used for irrigation. All rainwater from the roof is additionally treated with UV light so tha it can be used throughout the building for showers and drinking. These initiatives are part of the architects' philosophy of environmental responsibility Casa Uco Winery in Argentina has a minimalistic design. The building resembles a telescopic barn. It gradually increases in size as its internal functions, located within a single processing line, change. The 100-metre construction is made of concrete and metal plates providing thermal insulation. It open orientation from west to east allow controlled sunlight, indirect lighting and ventilation by Ventur effect taking advantage of the predominant Zond a barn.

Apart from taking into consideration natural environment conditions and renewable energy, the chitects also use ecological building materials.

A good example of this practice is the BRUMA winery from the wine-growing district of Valle de Guadelupe in Mexico. The symbol and central point of the object is a 300 year old oak growing in the centre of the barrel hall. Constructio and finishing materials include recycled wood steel, rammed earth, and rocks. The winery is tucked underground close to a small water body that helps maintaining appropriate temperature Wooden battens on the elevation are naturally discoloured and have various shades, which gives the building an interesting earthy texture. Light in the elevation. Local plants cover the roof of the winery. A part of the complex are curved rammedearth partition walls that integrate the building with dusty, green and red landscape of the valley even more.

The designers of New BIO Winery in Villorba, Italy, paid particular attention to the origin of materials they used. The building, also reinterpreting a traditional barn, was constructed mostly of endemic beech wood from Cansiglio, a forest area certified in accordance with the PEFC (Programme for the Endorsement of Forest Certification), which follows the principle of sustainable forest management. Choosing this material, the architects wanted to specting forest areas and emphasise the eco nature of wine produced in the winery. Thereby they made a reference to the context of classical rural buildings from Treviso province.

Another example of using natural building materials is the Domaine Les Aurelles winery in Nizas, France. It was built entirely of solid limestone from

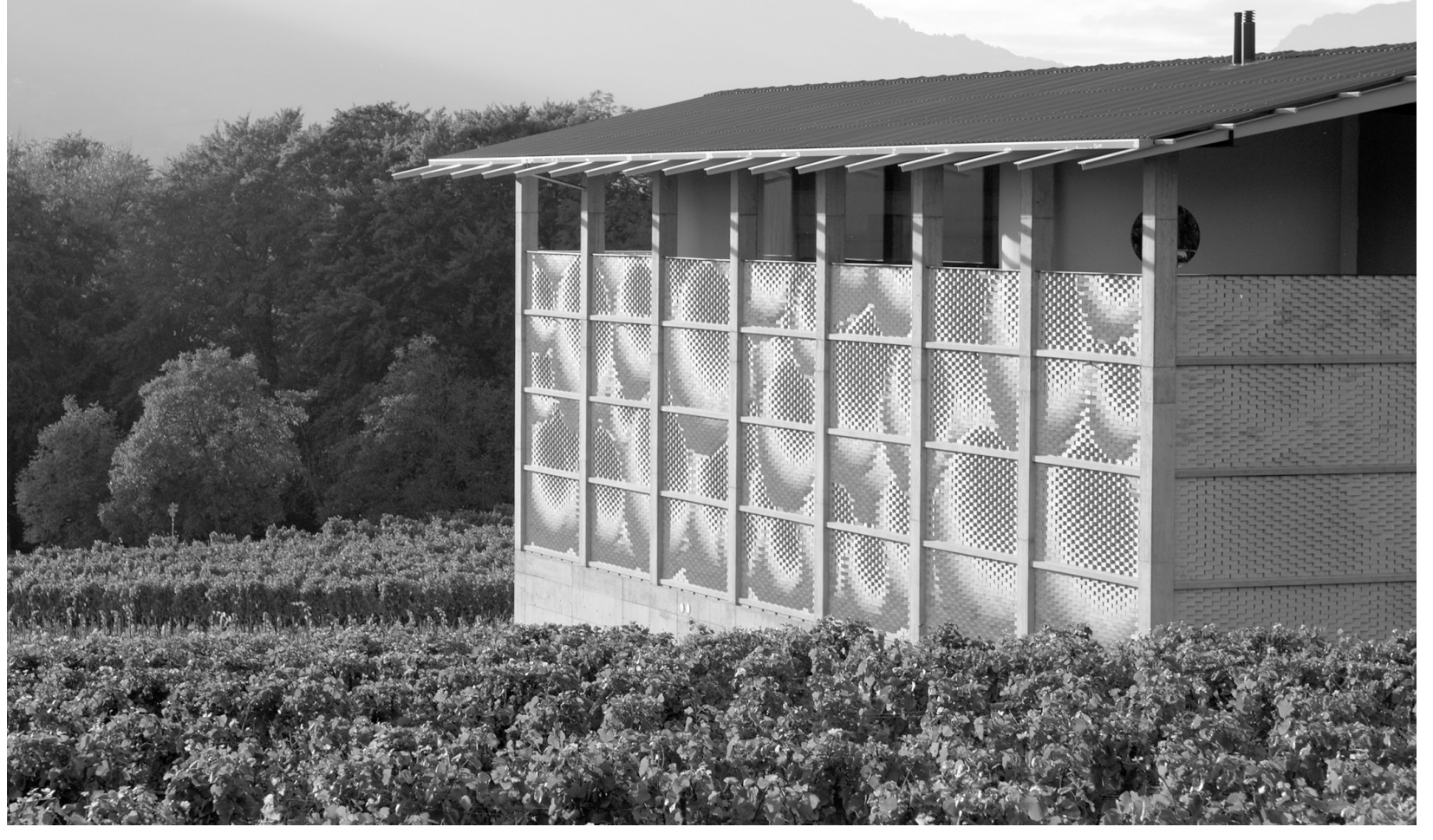

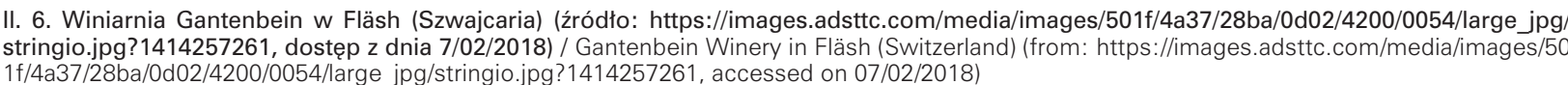

Projektanci New BIO Winery w Villorba we Włoszech zwrócili szczególną uwage na pochodzenie zastosowanych materialów budowlanych. Budynek równiez reinterpretujacy bryła wzorzec wiejskiej stodoły został wykonany w większości z bukowego drewna z obszaru Cansiglio, które jest tam gatunkiem endemicznym. Sa to obszary leśne certyfikowane zgodnie z programem PEFC (Program Zatwierdzania Certyfikacii Leśnei), uwzgledniajacy zasade zrównoważonej gospodarki leśnej, Wybierajac taki materiał architekci chcieli zwrócić uwi lesnej. Wybierając taki mane áć odwedzacy obszarow leśnych oraz pock no kick tu klasycznych budynków wiejskich prowincji Treviso. tu klasycznych budynkow wiejskich prowincji Treviso. .

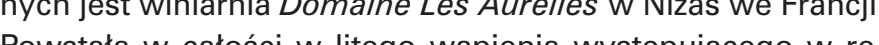
Powstała $w$ całości $w$ litego wapienia występującego $w$ regionie. Zbudowano z niego m.in. Pont du Gard, rzymski wiadukt niedaleko Nimes. Kamień cięto na bloki $65 \mathrm{~cm}$ ważące 3 tony. Nie połączono je cementem aby nie zaburzyć przez to warunkow klimatycznych pomieszczen. Użyto tradycyjne metody z czasów rzymskich. Bloki kładziono na sobie, a połączenia zostały wypełnione zaprawa wapienną. Całość tworzy zewnętrzny obwód 61 na 11 metrów. Budynek strukturą przypomina Grecką swiątynię. Swiatło dzienne może wejść tutaj tylko przez dfugą szczelinę zaraz pod stropem. Kamienie dzialają jak jednostka chłodząca, absorbując ciepło w dzień i oddając go do otoczenia w nocy. Zaprojektowano zielony dach, z grubą warstwą podłoża działająca jako bufor klimatyczny. Całość projektu zbudowano w sposób wernakularny zgodnie z zamiłowaniem właścicieli winnicy do natury i klasycznyc wzorców architektonicznych. the region, used to construct, among other things, Pont du Gard, a Roman aqueduct near Nimes. The stone was cut into $65 \mathrm{~cm}$ blocks weighing 3 tonnes each. They were not joined with cement in order to avoid disrupting the climate of the interior. A traditional method from the Roman times was used. Blocks were placed one on another and the spaces between them were filled with lime mortar. The of the building resembles a Greek temp. Daylight can enter only through a long gap under the ceiting. Stones work as a cooling unit, absorbing heat during the day and transferring it to the outside at night. A green roof with a thick layer of soil acting as a thermal buffer was designed. The entire object was built in a vernacular manner, following owners' admiration towards nature and classical architecture.

Gantenbein Winery in Fläsh, Switzerland, combines modern technologies and traditional materials. The building, nestled in the vineyard, has a concrete skeleton and is connected with the cellar of the existing winery with a tunnel. In elevation is made of offset sandstone bricks semi-transparent and creates a relief structure resembling a basket full of grapes. The gaps on the wall let in light and air, but isolate from direct sunlight, which results in a pleasant working atmosphere. The inside resembles a Moroccan house penetrated by thin streaks of light. Each change of perspective provides a new image which looks as though the walls were moving [i. 6]. This effect was achieved thanks to cooperatio 
Winiarnia Gantenbein w miejscowości Fläsh w Szwajcarii technologie $z$ tradycyjnymi materiałami budowlanymi. Budynek wtulony $\mathrm{w}$ winnice posiada betonowy szkielet $\mathrm{i}$ jest połączony podziemnym przejściem z piwnicą istniejącej winiarni. Elewacja wykonana została z offsetowych cegieł z piaskowca, ułożonych pod różnym katem z otwartymi spoinami. Całość jest półprzeźroczysta i tworzy strukture płaskorzéby przypominaiącą kosz wypetniony winegronami. Przerwy w ścianie wpuszczaja swiatto

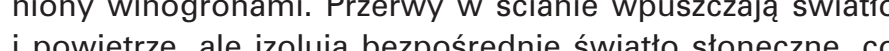
t pow trzy przyjemna atmosfere pracy. Whetrze hali przypo, co na średek Marokaniego domu, do którego wnikaja cie na srod ṕ tywy prynosi widzowi nowy obraz co daje wraze per jak tywy praynosi widzow nowy obraz co daje ważenie jakby mury sie poruszaly [1. G]. Efekt uzyskano dzieki wspolpracy $z$ z row go robola, Kory ukadal cegly dokladnie wedhy wczesniej zdefiniowanego wzoru oraz opracowali sposób nakładania srodka wiążącego, klory pozwoli nie stosowac elementów zbrojeniowych. Temperatura w Whiarni niezaleznie od pory roku utrzymywana jest na poziomie między kilka a 20 stopni. Zastosowano panele z poliwęglanu wewnątrz by chronic kadzie przed wiatrem. Sciany piwnicy na niższej kondygnacji gdzie leżakują wina oblepione zostały gliną, co pozwala utrzymac optymalną wilgotnosć. Projektanci zafascynowan architekturą rustykalną stworzyli budynek będący unikalnym efektem współpracy winiarstwa, architektury i innowacji technologicznych.

\section{PODSUMOWANIE}

Dokonana analiza wskazuje wyraźnie, że architektura współczesnych enotek charakteryzuje się rozwiązaniami przyjaznymi dla środowiska naturalnego. W projektach uwzględnione zostało usytuowanie budynków, pozwalające na optymalne wykorzystanie światła dziennego i naturalnej wentylacji. Budynki często zagłębione są w terenie aby zminimalizować wpływ różnic temperatury $i$ wilgotności oraz wizualną ingerencję w otaczający krajobraz. Stosowane są zielone dachy i celowe kształtowanie przestrzeni zielonej na terenach przyległych. Projektanci przykładają dużą uwagę do odnawialnych źródeł energii oraz ekologicznych materiałów. Widoczny jest również szacunek dla tradycji zarówno architektonicznej jak i winiarskiej. Rozwiazania funkcjonalne zwykle promują naturalne sposoby produkcii wina, a forma harmonijnie wkomponowuje sie w krajobraz i sąsiednie budynki. Wiele z obiektów poprzez nowoczesna reinterpretacje tradycyjnych wzorców architektonicznych można zaliczyć do nurtu krytycznego regionalizmu. Wszystkie opisane realizacje sa to budynki sektora prywatnego. Właścicielom winnic we współpracy z archira prywatnego. Wiaścicielom winnic we wspołpracy z archinam ajaje się uzyskac kompromis między formą przyjazna naturze, funkcjonalnością i nowatorskimi rozwiązaniami. Opisywane winiarnie powstały w latach 2008-2016 (wyjątek Domożliwie Akrelles - 2001r.). Wybor miał za zadanie ukazanie enoteki. Architekci, wśród których znajduja sie sławy światowego formatu, wywiązali się z powierzonego im zadania znakomicie. with scientists from ETH Zurich. They constructed a binder application allowing not using rebar. The temperature of the winery is kept between les than ten and 20 degrees regardless of the season. volycarbonate panels were used inside to protec covered in clay to mantain appropriate humidity. The architects, fascinated by rustic architecture, created a building being a unique result of operation between viniculture, architecture, technological innovations.

\section{CONCLUSIONS}

This analysis clearly indicates that the architecture of contemporary wineries is characterised by environment-frindy solutions. The designs take into consideration the location of the buildings, which allows using daylight and natural ventilathe ground in order to minim a on sunk into perature and humidity differences as well as visual interference with the landscape. Green roofs and deliberate shaping of adjacent green areas are used. Designers attach great importance to renewable energy and ecological materials. Re spect for architectural and wine sector tradition was also observed. Functional solutions often promote natural methods of wine production and the form is in harmony with the landscape and neighbouring buildings. Many objects fall within critical regionalism due to modern reinterpretation of traditional architecture they represent. All the described realisations are private secto buildings. Vineyard owners in cooperation with tween environment-friendly form, funtise beand innovative solutions. The described wineries were constructed between 2008 and 2016 (except for Domaine Les Aurelles from 2001). The selection aimed at presenting a possibly up-to-date approach of the architects to wineries. The architects, some of whom are world-famous, did an excellent job.

ENDNOTES World, Cambridge University Press, 1997 Architecture of the 2Frampthon K., Towards a Crtical Regionalism: Six points of
an architecture of resistance, 1893 .
${ }^{3}$ Celadyn W., Architektura a systemy roślinne. Studium relacii miedzy elementami architektonicznymi a roślinnym-
Monograph 134, Cracow University of Technology, Cracow

4 Zimny H. Ekologia miasta, Agencia Reklamowo-Wydawni5 Dubel K., Uwarunkowania przyrodnicze, w planowaniu przestrzennym, Wydawnictwo Ekonomia i Środowisko, Bi 6 The New Charter of Athens 2003: The European Council of
Town Planners' Vision for Cities in the 21st century. Firenze 7Kamionka L.W. - Architektura zrównoważona i jej standardy
na przykładzie wybranych metod oceny, Monograph M30. Kielce University of Technology, Kielce 2012
\& Bauman K., Smak architektury, Fundacja Architektów, War-
saw 2010 University Press, 1997
2 Frampthon K., Towards a Critical Regionalism: Six points of an architecture of
resistance. 1983 . ${ }_{3}$ Celaldyn $W$. Architektura a systemy roślinne. Studium relacii mieddy elemen-
tami architektonicznymi a rosslinnymi. Monografia 134, Politechnika Krakowska. Kraków 1992 Zimny H., Ekologia miasta, Agencja Reklamowo-Wydawnicza, Warszawa 2005
"Dubel K., Uwarunkowanaia przyrodnicze w planowaniu przzestrzennym, Wydawnictwo KKonomia i Srodowisko, Biatystok, 2000
6 F Furman S., Wyporek B (ttum.), Nowa Karta Ater Curman S., Wyporek B (tlum.l., Nowa Karta Ateńska, Alinea, Firen, 2003 Kamionka L.W. - Architektura zrównoważona i jej standardy na przyktadzie wy-
branych metod oceny, Monografia Nr M30, Politechnika Swiętok rzyska, Kielce 2012
8 Bauman K.. Smak architektury, Fundacia Architektów, Warszawa 2010
9 htros

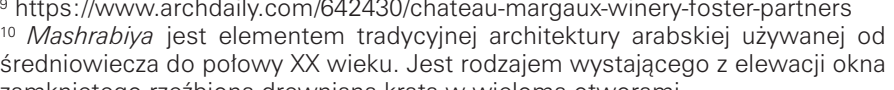

LITERATURA

11] Bańka A., Społeczna psychologia środowiskowa, Wydawnictwo Naukowe (1) Banka A., Spoteczna

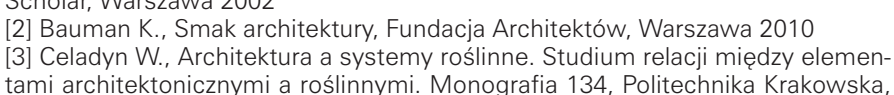
Krakiow 1992
[4] Ching F.D.K., A Visual Dictionary of Architecture, Van Nostrand Reinhold, New
York 1995 .

[5l Chmielewski W. Regionalizm wspótczessnej architektury reakcją na procesy
globalizacii, Politechnika Krakowska, Kraków 2017 [6] Dubel K., Uwarunkowania przyrodnicze w plan

dawnictwo Ekonomiai Srodowisko, Bialtystok, 2000
[7] Eden R.t. Wine \& design, W: Wallpaper*, 02/105/2017, s.165-166
[8] Frampthon K. Towards a Critical Regionalism. Six points of an architecture of

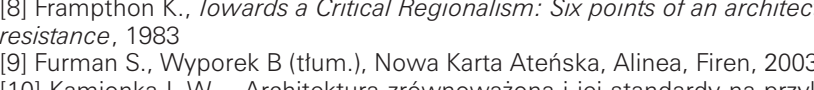

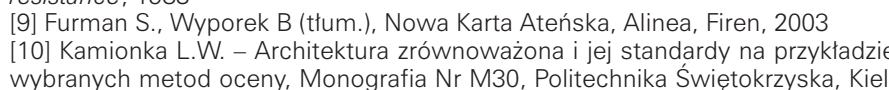
ce 2012 111] Le Corbusier, Karta Ateńska, tlum. T. Swoboda, K. Szeronos, Fundacja Cen112] Olivier P., Encycylszawa, of Vernacular Architecture of the World, Cambridg University Press, 1997
13] Ostrowska B 2 .

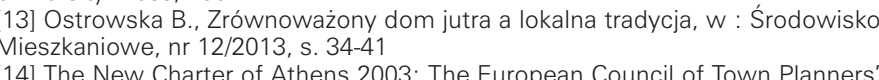
144 The New Charter of Athens 2003: The European Council of Town Planners'
Vision for Cities in the 21st cent Vision for Cities in the 21 st century. Firenze: Alinea, 2003.
[15] Woschek H.G., Duhme D., Friederichs K., Wine and architecture, Detail, Munich 2012
$[16]$ Wilkonson P., 50 teorii architektury, które powinieneś znać, PWN, Warszawa $17]$ Zimny H., Ekologia miasta, Agencija Reklamowo-Wydawnicza, Warszawa 2005 [18] https: //Www.archdaily.com/166598/ch
gne-architects (odstona z znia 14.01 .2018 ) (4.01.2018) 20] https://www.archdaily.com/803333/new-bio-winery-made-associati-architetti odstona dnia 19.1 .201818
[21] https://ww.archdaily.com/84032/port-phillip-estate-winery-woodmarsh [21] htps://Www.archdaily.com/84032/port-phillip-estate-winery-woodmarsh
(odstonaz z dnia 19.01.2018) [22] http://M
$27.01 .2018)$
[23] htp 23] http://Wwww.christian
lodstona z dnia 28.01.2018 作 -raed-abillama-architects (lodstona. z dnia 3.02 .2018 ) paso-robles-calitornia-landscape/ / odstona z z dnia 3.02.20

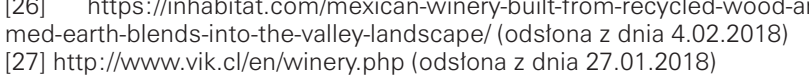

https:I//Www.archdally.com/642430/chateau-margaux-winerr-foster-partners
${ }^{10}$ Mashrabiyy is an Mashrabiya is an element of traditional Arabic architec-
ture used from the middle ages until the middle of the 20 th
century. It is a type of projecting window

BIBLIOGRAPHY

11] Bańka A., Społeczna psychologia środowiskowa, Wy dawnictwo Naukowe Scholar, Warsaw 2002 Bauman K., Smak architektury, Fundacja Architektów. 3] Celadyn W., Architektura a systemy roślinne. Studium relacji miedzy elementami architektonicznymi a roślinnymi.
Monograph 134, Cracow University of Technology, Cracow 1492
4) Ching F.D.K. A A Visual Dictionary of Architecture, Van Nostrand Reinhold, New York 1995

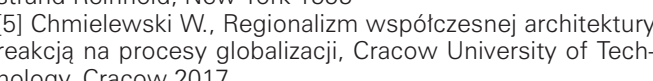
nokggy, Cracow 2017
[6] Dubel K., Uwaru

b] Dubel K., Uwarunkowania przyrodnicze w planowaniu
przestrzennym, Wydawnictwo Ekonomia i Środowisko, BiaNystok, 2000 Wine \& design, in: Wallpaper*, 02/05/2017,
7l] Eden R., Wine B] Frampthon K., Towards a Critical Regionalism: Six point of an architecture of resistance, 1983
[9] Furman S.,Wyporek B (tlum.), Nowa Karta Ateńska, Ali-
nea, Firen, 2003 [10] Kamionka L.W. - Architektura zrównowazona i jej stan-
dardy na przykladzie wybranych metod oceny. Monograph dardy na przyktadzie wybranych metod oceny, Monograph
M30, Kielece University of Technology, Kielce 2012
[111 Le Corbusier, Karta Ateńska, translation: T. Swobo-
da, K. Szeronos, Fundacja Centrum Architektury, Warsaw [12] Olivier P., Encyclopedia of Vernacular Architecture of
the World, Cambridge University Press, 1997

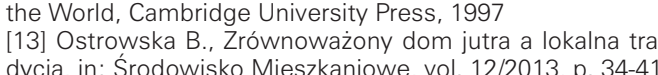
dycia, in: Środowisko Mieszkaniowe, vol. 12/2013, p. 34-41
[14] The New Charter of Athens 2003: The European Council of Town Planners' Vision for Cities in the 21 st century.
Eirenze: Alinea 2003. Firenze: Alinea, 2003.
[15] Woschek H.G., Duhme D., Friederichs K., Wine and ar-

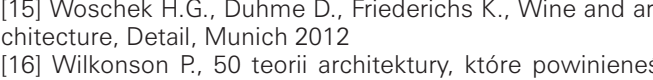
[16] Wilkonson P., 50 teorii architektury, które powinienes
znać, PWN, Warsaw 2011 .
[17] Zimny H., Ekologia miasta, Agencja Reklamowo-Wy-
dawnicza, Warsaw 2005 dawnicza, Warsanw 2005
[18] https://www.archdaily.com/166598/chateau-barde[18] hittps://Www.archdaily.com/166598/chateau-barde-
-haut-winery-nadau-lavergne-architects (accessed on
$14 / 01 / 2018)$ [19] https://www.archdaily.com/642430/chateau-margaux-
-winery-foster-partners (accessed on 14/01/2018) [20] https://Www.archdaily.com/803333/new-bio-win-
ery-made-associati-architetti laccessed on 19/01/2018) 21] 21 - https:///www. archdaily.com/84032/port-phillip-es [22] hitt:://Www.archello.com/project/casa-de-uco-winery
laccessed on 27/01/2018) [2accessed on 27/01/2018)
[23] http://www.christiandeportzamparc. com/en/projects/ winery-cheval-blanc/ (accessed on 28/01/2018)
[24] http://www.demagazine.co.ul/architecture/built-in-na035]/2018) [25] htps://Www.dezeen.com/2015/007/31/bar-arch-
tects-modern-law-winery-paso-robles-california-landscape/ (accessed on 03/02/2018)
[26] https:///inhabitat.com/mexican-winery-built-from-recy-
cled-wood-and-rammed-earth-blends-into-the-valley-landscape/ (accessed on 04/02/21218)
[27] http://www.vik.cl/en/winery.php laccessed on 